УДК $351: 342.1$

DOI: https://doi.org/10.26642/jen-2019-4(90)-199-206

\author{
В.О. Кучменко, к.е.н. \\ О.М. Івченко, магістрант \\ O.М. Герасимчук, магістрант \\ Державний університет «Житомирська політехніка»
}

\title{
Публічне управління в сфері правоохоронної діяльності
}

\begin{abstract}
Стаття присвячена особливостям формування ознак публічного управління в умовах стратегічних змін. У статті спрямовано увагу на роль правоохоронних органів при здійсненні публічного управління в Україні. Розглянуто основні напрями вдосконалення публічного управління в межах євроінтеграційної реформи. Визначено етапи процесу розвитку публічного управління в рамках державно-суспільних відносин. Проаналізовано зміст $i$ особливості правоохоронної функиії держави. Зазначено, щзо в умовах значних сочіально-політичних змін актуалізується потреба розробки й втілення принципово нових підходів до реалізаціі правоохоронної функиї держави. Зауважено, щзо подолання обмеженості здійснення правоохоронної функиії виключно правовими формами і активне застосування форм неправового змісту, по-перше, дає змогу охопити правоохоронною діяльністю гранично широке коло суспільних відносин і процесів; по-друге, сприяє залученню до правоохорони недержавних організацій $і$ громадян; по-третє, відображає об'єктивну закономірність, характерну для діяльності правової держави. Досліджено роль правоохоронних органів демократичної держави в забезпеченні правопорядку. Правоохоронні органи розглянуто як державні органи, уповноважені на здійснення контролю за дотриманням законодавства у певній визначеній галузі права, застосування примусу для забезпечення виконання поставлених перед ними завдань. Розкрито зміст правоохоронних органів держави, організація $i$ порядок діяльності яких визначаються законом. Розглядаються актуальні проблеми підготовки та організаціі управлінських рішень сфери правоохоронної діяльності, зокрема антикорупційної. Розглянуто елементи публічного управління відносно кожного з суб'єктів правоохоронної діяльності антикорупиійного значення.
\end{abstract}

Ключові слова: публічне управління; державний орган; правоохоронні органи; громадськість; антикорупційні суб'єкти управління; НАЗК; НАБУ; САП; АРМА.

Постановка проблеми. Сучасним стратегічним завданням державної влади $є$ встановлення інноваційної ідеології адаптованої за європейським зразком в напрямі функціонування правоохоронних органів як діяльності, в основу якої покладається забезпечення реалізації прав і свобод громадян, забезпечення правовстановлювальних, правозабезпечувальних дій. Відповідно, система державного управління повинна змінити власну парадигму в напрямі ефективного публічного управління [1, с. 5]. Вагомим завданням повинно бути наближення влади до народу, що наразі забезпечується пробудженням в останнього інтересу до державотвірного процесу, активізація дій громадськості як активного суб'єкта політвзаємодії, що наділений як справжніми інструментами ініціювання повновладних проектів, так і можливістю контролю за їх реалізацією.

Аналіз останніх досліджень і публікацій. Окремі аспекти функціонування сфери публічного управління стали наріжним каменем досліджень 3 державного управління (В.Мандибура, В.Лобас, О.Мельниченко та ін.), контролю та адміністрування (І.Грицяк, М. Колеснікова та ін.), правового забезпечення (К.Рябець, Р.Мельник, С.Куйбіда, М.Білинська та ін.) тощо. У більшості випадків зазначений вплив досліджувався переважно як реалізація державного управління, державної політики й державне регулювання. Утім останнім часом у своїх публікаціях чільні науковці (В.Бодров, С.Борисевич, І.Грицяк, Р.Мельник, О.Лазор, В.Лунячек, О.Кобзар, О.Оболенський, Н.Гончарук, І.Сурай, В.Банаха, О.Сосніна, П.Жукаускаса, Й.Ввайнхардт та ін.) дедалі активніше застосовують споріднену дефініцію «публічне управління», що наголошує на актуалізації нових аспектів даної проблематики. Разом 3 тим, малодослідженими $є$ питання публічного управління окремих сфер державного управління, в тому числі сфери правоохоронної діяльності.

Мета статті полягає у з'ясуванні особливостей публічного управління у сфері правоохоронної діяльності.

Викладення основного матеріалу дослідження. Розкриття поняття та сутності публічного управління зіштовхується 3 суперечливими підходами до розуміння сутності управління в системі державних органів, особливо сфери правоохоронної діяльності.

Насамперед, публічне управління традиційно розуміється як вид діяльності, який характеризується як мистецтво i наука управління державними справами, при цьому приділяється особлива увага 
питанням роботи 3 людьми, комерційними, некомерційними, фінансовими організаціями i домогосподарствами на основі пріоритетів встановлених законів, правил і процедур. У поняття «публічне управління» входять функції виконавчих органів влади держави.

Савенюк В. ототожнює публічне управління з будь-якою діяльністю, що здійснюється органами державної влади: законотворча, правозастосовна, організаційна, контрольна та інші види діяльності [1, с. 8]. На думку Аль-Атті І., розкриття сутності «публічного управління» здійснюється через систему впливу владного суб’єкта на об'єкт (суспільні відносини) [7]

Битяк Ю., Гаращук В. зазначає, що визначення особливостей публічного управління будується на нормах конституції держави, що містить в собі цілі, в т. ч. завдання публічного управління, що обумовлено не тільки чинним політичним режимом, але й політичною ідеологією [8].

Нижник Н., Лахижа М., Гончарук Н. [13] звертають увагу на «формування переконання в закономірності переходу від традиційного державного управління до публічного» та зазначають про оптимальність поліпшення ситуації в державі. Новак-Каляєва Л. публічне управління визначає через діяльність органів держуправління, місцевого самоврядування, інститутів громадянського суспільства й представників приватного сектору в межах визначених закондавчо (повноваження і функціональні обов'язки з організації, планування, керівництва, контролю й координації) в напрямі реалізації й формування управлінської політики розвитку держави, рішень суспільного значення іiі адміністративнотериторіальних одиниць. Значна роль приділена високому рівню громадської підтримки й консолідації суспільства [13, с. 144].

За Ю.Шаровим, дефініція «публічне управління» має три вектори: врядування як процес колективного створення й реалізації стратегічних рішень на базисі механізмів консенсусу формування й узгодження політики та координації дій ключових учасників; адміністрування як чіткий розподіл обов'язків і повноважень поміж учасниками процесу й інформаційно-комунікативне узабезпечення горизонтальної і вертикальної координації дій серед суб'єктів врядування; менеджмент як взаємозв'язок процесів, що опираються на інституційний базис адміністрування та спрямовані на убезпечення виконання стратегічних рішень із застосуванням раціональних управлінських технологій, засобів, методів та форм управління» [17].

На думку Р.Мельника, публічне управління являє собою різновид суспільно корисної діяльності, який здійснюється певною сукупністю суб’єктів, зокрема органами державної влади [11, с. 96]. Погоджуючись 3 думкою Р.Мельника, що «влада далеко не завжди пов'язана з примусом» зазначимо про важливість використання позапримусових механізмів (на відміну від «державного управління»). Не варто «розширювати зміст публічного управління за рахунок внутрішньоорганізаційної діяльності органів виконавчої влади; публічне управління проявляється лише у зовнішніх відносинах органів виконавчої влади з іншими органами публічної влади, а також приватними особами» [11, с. 97].

Тобто, одні вчені визначають публічне управління як введення нової інституціональної економіки, державного управління, а інші використовують його для позначення зміни в політиці:

1. Створення більш складних і квазіринкових систем, що розвиваються.

2. Зміна від ієрархічного управління до управління контрактами у державній та муніципальній службі.

3. Різні підходи до управління стратегічними центрами і сфеами дії, на основі оцінки стану державної сфери впливу і контрактації стратегічних посадових обов’язків державних службовців.

4. Скасування i скорочення неефективних структур i організацій (в тому числі i в сфері правоохоронної діяльності).

5. Впровадження нових управлінських концепцій, таких як управління через вплив, створення мережі для відповідних держорганів, створення стратегічних альянсів, звязків між державними сферами впливу.

6. Рух від стандартних форм управлівння до більш гнучких і різноманітних форм менеджменту.

Разом $з$ тим, в даний час в теорії публічного управління в Україні розглядаються два підходи:

а) публічно-адміністративний підхід, де сутність управління - вплив державних органів на людину, суспільство, суспільні відносини;

б) маркетинговий підхід, де публічне управління - взаємовідносини державних структур і людини, суспільства на основі їх відкритості, інформативності, прозорості.

Від їх розгляду і вираження сутності процесів, що відбуваються в сфері державного управління, залежить і сутність визначення публічного управління.

В цілому дефініцію «публічний» не варто автоматично використовувати як тотожну терміну «державний». «Публічне управління» як модель управління сферою правоохоронної діяльності суспільства отримало інший сутнісний зміст. Публічне управління $є$ різновидом суспільно корисних правовстановлювальних, правозабезпечувальних дій, які здійснюються певною сукупністю суб'єктів, а саме правоохоронними органами державної влади. Відповідно, повною мірою повинні активізуватися позапримусові механізми (на противагу «державному управлінні», що базується на механізмі примусу 
суб'єктів управління) й проявлятися у зовнішніх взаємовідносинах органів виконавчої влади з іншими органами влади публічного управління, а також приватними особами [12, с. 42].

Публічне управління убезпечує помітне зростання рівня ефективності управлінської діяльності за умови високого показника громадської підтримки й консолідації суспільства довкола спільних цілей.

Процес розвитку публічного управління в межах державно-суспільних відносин можна розділити на такі етапи:

1. Державне управління як сукупність офіційних структур влади з чіткою ієрархією між органами управління.

2. Управління, орієнтоване на підвищення ефективності використання ресурсів залежно від особливостей ринкових відносин. Розширення приватного сектора економіки і зниження питомої ваги державної власності в економіці.

3. Орієнтація публічного регулювання на результати партнерства між державним і приватним секторами економіки.

4. Управління як система цінностей політики, за допомогою яких відбувається раціональне управління економічними, соціальними і політичними компонентами суспільного життя.

Таким чином, публічне управління - це вплив суб'єкта управління (органів державної влади (в тому числі і правоохоронних органів) на об’єкт управління (ті чи інші суспільні відносини) у взаємодії 3 представниками бізнес-структур, некомерційних громадських організацій й інших осіб, зацікавлених у результатах, прийнятих представниками владних структур рішень.

Важко переоцінити роль правоохоронних органів при здійсненні публічного управління в Україні. Більш того, правоохоронні органи $є$ правозастосовними органами, i самі здійснюють публічне управління [10, с. 71$]$.

В юридичній літературі під правоохоронним органом запропоновано розуміти «державний орган, наділений правами і обов'язками із здійснення правозахисної й правозастосовної діяльності. Виконуючи соціально значущі ролі в області права і правових відносин, правоохоронні органи як інституційне владне утворення безпосередньо беруть участь у реалізації правової політики держави. Вони є частиною механізму іії організації та реалізації, інструментом правового регулювання суспільних відносин в країні, суб'єктом міжнародних правових комунікацій держави, забезпечують реалізацію норм права, контроль за їх виконанням.

Основу наведеного складають чотири істотні ознаки: права і обов'язки правоохоронного органу врегульовані нормами права; кожен правоохоронний орган здійснює свою діяльність шляхом проведення специфічних дій; правозахисний й правозастосовний характер (примусовий в тому числі) специфічних дій правоохоронного органу; певна процесуальна форма здійснення специфічних дій. Тільки при наявності всіх чотирьох суттєвих ознак можна встановити приналежність того чи іншого державного органу до правоохоронних органів.

Викладене дозволяє нам висловити кілька міркувань.

По-перше, публічне управління здійснюється правозастосовними органами, в тому числі i правоохоронними органами.

По-друге, правоохоронними органами є виключно державні органи.

У вітчизняній юридичній літературі питання про склад і перелік правоохоронних органів поки не вирішено; він досі залишається дискусійним [8]. Найбільш доцільним і обгрунтованим видається думка вчених-юристів, які на основі розкриття і характеристики змісту і форм правоохорони як діяльності зараховують до державних правоохоронних органів судові органи, прокуратуру, органи служби безпеки, органи внутрішніх справ, органи охорони державного кордону, органи юстиції, антикорупційні органи тощо [13, с. 26]. За змістом і характером, конкретним завданням професійної діяльності перераховані правоохоронні органи є відносно самостійними державними органами, виконують відмінні ролі в структурі державної влади. Одночасно діяльність правоохоронних органів здійснюється на основі певних субординаційно-координаційних управлінських взаємовідносин. Вони мають єдині ознаки (державна діяльність, діяльність уповноваженого державного органу, примусова діяльність, діяльність на основі забезпечення захисту й балансу інтересів особистості, суспільства і держави), у них спільна мета охорона права, забезпечення правового порядку, громадської та державної безпеки, безпеки особистості, що дає підставу розглядати правоохоронні органи в їх сукупності як системне інституційне утворення в структурі державної влади.

Сьогодні основними напрямами вдосконалення публічного управління в межах євроінтеграційної реформи залишаються:

1. Зниження надмірного державного регулювання й активізація системи публічного управління.

2. Підвищення якості державних послуг.

3. Підвищення ефективності органів влади, подолання корупції.

4. Підвищення інформаційної відкритості й прозорості сфери управління. 
Так в напрямі забезпечення ефективної системи публічного управління правоохоронної діяльності вагоме значення має антикорупційна стратегія розвитку. Сфера публічного управління правоохоронних органів за напрямом антикорупційної діяльності формує такі суб'єкти впливу: НАЗК, НАБУ, Спеціалізована антикорупційна прокуратура (САП), Національне агентство України з питань виявлення, розшуку та управління активами, одержаними від корупційних та інших злочинів (АРМА), але разом 3 тим, не кожен такий суб’єкт управління отримав задовільне матеріальне і кадрове забезпечення та розпочав роботу [12].

Дані суб'єкти є незалежними від парламенту та мають закритий характер функціонування, що ускладнює організацію контролю над ними. Серед потенційних варіантів удосконалення парламентського моніторингу в цій сфері $є$ створення у відповідному комітеті ВРУ підкомітету 3 необхідними контрольними повноваженнями. Для забезпечення успішної роботи державних органів, що реалізують антикорупційну політику, варто забезпечити:

- самостійність та незалежність цих органів від влади;

- залучення громадянського суспільства у діяльність антикорупційних органів;

- налагодження співпраці органів державної влади з місцевим самоврядуванням;

- стовідсоткове фінансово-матеріальне забезпечення.

Як антикорупційні суб’єкти публічного управління правоохоронної діяльності також функціонують: Президент України, Уряд, парламент, судова влада й громадськість. Але разом 3 тим, існує багато проблем щодо висвітлення управлінських функцій цих суб'єктів та, відповідно удосконалення їхніх структур. Ця відповідальність належить ВРУ, що виконує законодавче врегулювання всіх складових антикорупційної діяльності, регулює проведення реформ кримінального законодавства.

Антикорупційні правоохоронні органи одночасно є суб'єктами 3 високими корупційними ризиками, що характеризуються [9]:

- повноваженнями, що зв’язані з розподілом значних фінансових ресурсів;

- свободою дій в управлінській діяльності;

- співпрацею з іноземними фондами, інвесторами та організаціями.

Пріоритетним завданням української влади та суспільства є реалізація Антикорупційної стратегії, основні заходи якої визначені Законом України «Про засади державної антикорупційної політики в Україні на 2014-2017 роки» від 10.14.14 р. № 1699-VII. Відповідно до даного Закону, пункту 1, розділу 2 першочерговим є створення спеціально уповноваженого органу щодо запобігання корупції [2].

Сфера публічного управління цього органу може бути активована лише за умови незалежності та самостійності, при забезпеченні персоналом і фінансовими ресурсами для протидії корупції. Дані вимоги відповідають Конвенції ООН проти корупції та Кримінальній конвенції Ради Європи про боротьбу 3 корупцією.

Зазначимо, що до складу «антикорупційних органів» входять різні інституції, які виконують певну роль у боротьбі $з$ корупцією, однією 3 них $є$ СБУ. До завдань СБУ входить протидія корупції організованої злочинної діяльності у сфері управління і економіки. Проте у Законі України «Про запобігання корупції» 1700-VII він виключений з переліку спеціально уповноважених суб'єктів у сфері протидії корупції [3].

Результативність боротьби 3 корупцією залежить від об'єднання уповноважених суб'єктів, покликаних перешкоджанню корупційним правопорушенням. Зазначимо, в Україні діють три спеціалізовані суб'єкти в боротьбі проти корупції це - НАЗК, НАБУ, САП. До того ж існує ще один суб'єкт - це ДБР, що вже створений, але він ще не функціонує. Служба безпеки України (СБУ), Національна поліція, органи прокуратури є поліфункціональними органами, які забезпечують законність та регулюють правовідносини, також не обмежуються антикорупційними заходами.

Національна поліція, що є спеціально уповноваженим суб'єктом публічного управління у сфері боротьби із корупцією, виконує поліцейські послуги у сферах порядку, свобод та охорони прав людини, протидії злочинності, відповідно ст. 2 ЗУ «Про Національну поліцію» від 02.07.15 р. № 580-VIII [4].

Повноваження поліції до покладених на неї завдань у сфері протидії корупції:

- застосовувати заходи з метою виявлення кримінальних чи адміністративних правопорушень;

- зменшувати кримінальні та адміністративні правопорушення.

Відповідно до ст. 255 Кодексу України про адміністративні правопорушення, уповноважені особи Національної поліції вправі складати протоколи про вчинення адміністративних правопорушень, пов'язаних із корупцією за відповідними статтями КпАП: 172-4, 172-5, 172-6, 172-7, 172-8, 172-9 [1].

Сфера публічного управління Національної поліції активується за умови, якщо наявний конкретний факт виявлення корупційного або пов'язаного із корупцією правопорушення, тоді Національна поліція вправі запитувати інформацію від посадових осіб органів державної влади, органів місцевого самоврядування, юридичних та фізичних осіб, необхідну для виконання покладених на них функцій.

Зауважимо, що до органів держаної влади прийшло розуміння того, що знищення корупції як системного явища не можливо вирішити лише єдинм спеціалізованим антикорупційним органом. Таким 
чином, це зумовило створення в Україні структури мультиорганізаційної моделі, коли обов'язки боротьби із корупцією поділені між декількома органами.

Слід наголосити, що без достатньої незалежності антикорупційних органів неможливе належне виконання обов'язків. Тому у їх розпорядженні мають бути відповідні правові й матеріальні засоби. Насамперед необхідно створити законодавчу базу, яка чітко визначить повноваження антикорупційних органів.

Зважаючи на сказане вище, можна зробити висновок, що публічне управління сфери правоохоронної діяльності має відповідати міжнародним стандартам, передовій світовій практиці, а також враховувати особливості національної правової системи.

За даними, Національне агентство з питань запобігання корупції (НАЗК) - $\epsilon$ центральним органом виконавчої влади України, що має спеціальний статус i забезпечує реалізацію i формування антикорупційної політики держави. Дана структура задіяна в сферах антикорупційної політики: електронне декларування майна чиновниками, запобігання політичній корупції, регулювання та запобігання конфлікту інтересів, попередження та робота 3 викривачами, формування антикорупційної стратегії та реалізація антикорупційної політики.

В структурі публічного управління цього органу виокремимо такі підрозділи: департамент координації антикорупційної політики; департамент організації роботи із запобігання та виявлення корупції; Департамент моніторингу дотримання законодавства про конфлікт інтересів та інших обмежень щодо запобігання корупції; Департамент перевірки декларацій та моніторингу способу життя; Департамент з питань запобігання політичній корупції; Управління організаційно-адміністративного забезпечення; Управління інформаційно-аналітичних систем та захисту інформації; Управління плановофінансової діяльності, бухгалтерського обліку та звітності; Управління документального забезпечення та контролю; Управління персоналу; Управління правового забезпечення тощо.

НАЗК на противагу Національному антикорупційному бюро (НАБУ) є правоохоронним органом, що має превентивну функцію управління з створення й забезпечення дотримання правил, що дозволяють запобігти корупції. Відповідно до ст. 1 Закону України від 14.10.14 р. № 1698-VII «Про Національне антикорупційне бюро України», НАБУ $є$ «основним державним правоохоронним органом, на який покладаються попередження, виявлення, припинення, розслідування та розкриття корупційних правопорушень відповідно до вимог підслідності, а також запобігання вчиненню нових корупційних правопорушень, а окремі його підрозділи відповідно до чинного Кримінального процесуального кодексу України набувають статусу самостійного органу досудового розслідування» [5].

В структурі Національного антикорупційного бюро присутні такі підрозділи управління та відділи: підрозділи детективів, управління аналітики та обробки інформації, управління інформаційних технологій, оперативно-технічне управління; управління спеціальних операцій, управління по роботі 3 громадськістю, управління зовнішніх комунікацій, юридичне управління, управління внутрішнього контролю, управління бухгалтерського обліку та звітності тощо.

Боротьба 3 кримінальними корупційними злочинами $\epsilon$ основним завданням Національного антикорупційного бюро України. Активізація публічного управління за оперативно-розшуковими заходами та досудовими розслідування спрямована на перевірку на правдивість дій місцевого самоврядування, чиновників і представників державної влади. Контролюючими органами за діяльністю НАБУ $є$ Комітет 3 питань боротьби з організованою злочинністю і корупцією та Спеціалізована антикорупційна прокуратура.

При розгляді структури НАБУ виокремлюють ii управлінські повноваження. Нижче в таблиці 1 детально розберемо, які конкретно злочини Кримінального кодексу України розслідує цей «антикорупційний орган».

Національне антикорупційне бюро України при виявленні фактів злочинів корупційного характеру має право на розкриття інформації інших слідчих органів, при підтвердженні рішення Директора НАБУ та за погодженням із прокурором САП.

Закон «Про Національне антикорупційне бюро України» дає право НАБУ проводити оперативнорозшукові дії, під час досудового розслідування у кримінальних провадженнях. Фактично НАБУ містить в собі функції слідчих і оперативних підрозділів.

Для протидії корупції створено безпечні канали надання інформації у вигляді спеціальної телефонної лінії, офіційного вебсайту НАБУ у мережі Інтернет, поштового і електронного зв'язку або подання заяви і повідомлення про кримінальне правопорушення, у тому числі анонімної. Основні вимоги до анонімних заяв та повідомлень $є$ точні та фактичні дані корупції конкретної особи та можливість перевірки наданої інформацї

На даний час НАБУ активізує у своїй діяльності всі аспекти боротьби із корупцією в їх найбільш суспільно небезпечних проявах, що нині є абсолютно необхідним і виправданим рішенням. Наслідуючи міжнародний досвід у боротьбі з корупцією, в Україні створено САП. В Італії діє Національна прокуратура Антимафії, яка займається боротьбою із організованою злочинністю і відмиванням доходів, 
отриманих від злочинів, вчинених злочинним угрупуванням. В Іспанії існує окружна прокуратура щодо попередження економічних злочинів, пов’язаних із корупцією.

САП посилює зусилля НАБУ у напрямі протидії корупції. Антикорупційна прокуратура належить до структури Генеральної прокуратури України, проте становить самостійну ланку системи прокуратури України. Вона контролює діяльність НАБУ та представляє інтереси держави і громадян у випадках, пов'язаних з корупцією.

Відповідно до ст. 8 Закону України «Про прокуратуру» від 14.10.14 р. № 1697-VII [6], маємо такі функції діяльності САП (табл. 1).

Таблиия 1

Сфера публічного управління САП за антикорупиійною політикою

\begin{tabular}{|c|c|c|}
\hline № & Вид управлінського впливу & Характеристика дії \\
\hline 1. & $\begin{array}{c}\text { Нагляд за додержанням законів під } \\
\text { час проведення оперативно- } \\
\text { розшукової діяльності, досудового } \\
\text { розслідування НАБУ }\end{array}$ & $\begin{array}{l}\text { Реалізується в межах конституційної функції прокуратури } \\
\text { України за здійсненням нагляду за додержанням законів } \\
\text { органами, що здійснюють оперативно-розшукову діяльність, } \\
\text { дізнання та досудове слідство. Прокурори САП здійснюють } \\
\text { процесуальне керівництво досудовим розслідуванням, яке } \\
\text { проводиться слідчими НАБУ }\end{array}$ \\
\hline 2. & $\begin{array}{c}\text { Підтримання державного } \\
\text { обвинувачення у відповідних } \\
\text { провадженнях }\end{array}$ & $\begin{array}{l}\text { Реалізується в межах конституційної функції прокуратури } \\
\text { України з підтримання державного обвинувачення в суді; } \\
\text { логічним продовженням здійснення прокурорами САП } \\
\text { процесуального керівництва, яке проводиться слідчими } \\
\text { НАБУ }\end{array}$ \\
\hline 3. & $\begin{array}{c}\text { Представництво інтересів } \\
\text { громадянина або держави в суді }\end{array}$ & $\begin{array}{l}\text { Реалізується в межах конституційної функції прокуратури } \\
\text { України } 3 \text { представництва інтересів громадянина або } \\
\text { держави в суді }\end{array}$ \\
\hline 4. & $\begin{array}{l}\text { Здійснює міжнародне } \\
\text { співробітництво }\end{array}$ & $\begin{array}{l}\text { Не є самостійним видом управління, а лише спрямоване на } \\
\text { забезпечення реалізації питань провадження процесуальних } \\
\text { дій при розслідуванні кримінальних правопорушень та } \\
\text { інших питань, передбачених міжнародними договорами }\end{array}$ \\
\hline
\end{tabular}

Держава повинна сприяти вирішенню проблем корупції шляхом реалізації поставлених цілей у вищих ешелонах влади, реформування влади та закріплення відповідальності на горизонтальному рівні, розроблення проектів управлінських рішень, запровадження курсу навчання з державно-правових питань у вищих навчальних закладах 3 метою подолання необізнаності населення у цій сфері; фінансового контролю діяльності органів влади, залучення громадян до роботи у громадських радах, громадської експертизи тощо.

Відповідно до діяльності антикорупційної політики в Україні, законодавці прагнуть забезпечити тісну взаємодію НАБУ й САП та при цьому важливим стає ефект автономності. Такий ефект в умовах САП проявляється через діяльність та організацію (особливе місце розташування, формування кадрового складу, структура управління, законодавчі обмеження, автономність від інших органів прокуратури. Структура публічного управління САП сформована 3 таких підрозділів, що підпорядковані Генеральному прокурору Україні: відділ аналітично-статистичного забезпечення, управління процесуального керівництва підтримання держобвинувачення; відділ документального забезпечення.

Зауважимо, що самостійність правоохоронних антикорупційних органів є основою для встановлення відповідного рівня публічного управління із забезпечення виконання своїх функцій, тому у їх розпорядженні мають бути правові й фінансові засоби. Значну роль в розвитку сфери публічного управління повинні відігравати міжнародні стандарти, імплементація кращих зразків світової практики.

Висновки. Таким чином, публічне управління - це вплив суб'єкта управління (органів державної влади (в тому числі і правоохоронних органів) на об'єкт управління (ті чи інші суспільні відносини) у взаємодії з представниками бізнес-структур, некомерційних громадських організацій й інших осіб, зацікавлених у результатах прийнятих представниками владних структур рішень. Публічне управління убезпечує помітне зростання рівня ефективності управлінської діяльності за умови високого показника громадської підтримки й консолідації суспільства довкола спільних цілей. 
Повною мірою мають активізуватися позапримусові механізми (на противагу «державному управлінні», що базується на механізмі примусу суб’єктів управління) й проявлятися у зовнішніх взаємовідносинах органів виконавчої влади з іншими органами влади публічного управління, а також приватними особами. Правоохоронні органи в сучасних умовах $є$ одним із найбільш сильних i організованих публічних інститутів державної влади, які виконують соціально значущі завдання в інтересах особистості, суспільства і держави. В напрямі забезпечення ефективної системи публічного управління правоохоронної діяльності вагоме значення має антикорупційна стратегія розвитку. Сфера публічного управління правоохоронних органів за напрямом антикорупційної діяльності формує такі суб'єкти впливу: НАЗК, НАБУ, Спеціалізована антикорупційна прокуратура (САП), Національне агентство України з питань виявлення, розшуку та управління активами, одержаними від корупційних та інших злочинів (АРМА), але разом 3 тим не кожен такий суб'єкт управління отримав задовільне матеріальне і кадрове забезпечення та розпочав роботу.

Напрямами підвищення ефективності публічного управління сфери правоохоронної діяльності в Україні повинні стати: посилення ефективності розробки нормативно-правових інструментів розв'язання означених питань, створення та практичне значення спецкурсів для підрозділів управлінь та вищих навчальних закладів, формування високого рівня прозорості та відкритості діяльності органів державної влади й місцевого самоврядування на основі законодавчого врегулювання, активізація політики наказовості порушень чиновників у сфері корупції.

\section{Список використаної літератури:}

1. Кодекс України про адміністративні правопорушення від 07.12.1984 № 8073-Х : ред. від 05.05.2018 [Електронний ресурс]. - Режим доступу : http://zakon3.rada.gov.ua/laws/show/80731-10.

2. Про засади державної антикорупційної політики в Україні (Антикорупційна стратегія) на 2014-2017 роки : Закон України від 14.10.2014 № 1699-VII : ред. від 08.08.2015 [Електронний ресурс]. - Режим доступу : https://zakon.rada.gov.ua/laws/show/1699-18.

3. Про запобігання корупції : Закон України № 1700VII від 14 жовтня 2014 р. : ред. від 16.07.2019 [Електронний ресурс]. - Режим доступу : http://zakon4.rada.gov.ua/laws/show/170018.

4. Про Національну поліцію : Закон України від 02.07.15 p. № 580-VIII : ред. від 01.01.2019 [Електронний pecypc]. - Режим доступу : https://zakon.rada.gov.ua/laws/show/580-19.

5. Про Національне антикорупційне бюро України : Закон України від 14.10 .14 р. № 1698-VII : ред. від 05.06.2019 [Електронний ресурс]. - Режим доступу : https://zakon.rada.gov.ua/laws/show/1698-18.

6. Про прокуратуру : Закон України від 14.10.2014 № 1697-VII : ред. від 28.08.2018 [Електронний ресурс]. Режим доступу : https://zakon.rada.gov.ua/laws/show/1697-18.

7. Аль-Аmmi I.B. Публічне управління : сутність і визначення / I.B. Аль-Аmmi // Аспекти публічного управління. - 2018. - Т. 6, № 8. - С. 35-41.

8. Адміністративне право України : підручник / Ю.П. Битяк, В.М. Гаращук, О.В. Дьяченко та ін.; за ред. Ю.П. Битяка. - Київ : Юринком Інтер, 2007. - 543 с.

9. Гончарук Н.T. Вплив розвитку громадянського суспільства на публічне управління / Н.T. Гончарук, I.Г. Сурай // Державне управління: історія, теорія, впровадження : мат-ли наук.-практ. конф. за міжнар. участю, м. Київ, 28 трав. 2010 р. - Київ : НАДУ, 2010. - Т. 1. - С. 145-146.

10. Кобзар О.Ф. Взаємодія - невід'ємна складова управління в правоохоронній діяльності / О.Ф. Кобзар // Наукові записки Центральноукраїнського державного педагогічного університету імені Володимира Винниченка. Серія : Право. - 2017. - Вип. 2 (спецвип.). - С. 71-74.

11. Мельник Р.С. Категорія «публічне управління» у новій інтерпретації / Р.С. Мельник // Право і суспільство. - 2012. № 6. - C. 95-98.

12. Новак-Калясва Л.М. Деякі аспекти формування новітньої парадигми публічної влади на засадах прав людини / Л.М. Новак-Каляєва // Ефективність державного управління. - 2015. - Вип. 45. - С. 41-47.

13. Публічна адміністрація в Україні: становлення та розвиток / за заг. ред. А.В. Толстоухова, Н.Р. Нижник, H.T. Гончарук. - Дніпропетровськ : Моноліт, 2010. - 400 с.

14. Публічне управління та адміністрування в умовах інформаційного суспільства: вітчизняний і зарубіжний досвід / В.Воронкова, В.Банах, О.Соснін та ін. ; за заг. ред. С. Чернова. - Запоріжжя : ЗДІА, 2016. - 606 с.

15. Публічне управління. Термінологічний словник / уклад. : В.С. Куйбіда, М.М. Білинська, О.М. Петроє та ін. Київ : НАДУ, 2018. - 224 с.

16. Модернізація системи публічної влади в адміністративному районі України : автореф. дис. на здобуття наук ступеня канд. наук 3 держ. упр. : спец. 25.00.04 місцеве самоврядування / В.В. Савенюк. - Київ : Національна академія державного управління при Президентові України, 2018. - 20 с.

17. Шаров Ю. Європейські стандарти публічного управління: проекція на муніципальний рівень / Ю.Шаров, I. Чикаренко [Електронний ресурс]. - Режим доступу : www.nbuv.gov.ua.

\section{References:}

1. Verhovna Rada Ukrai'ny (2018), Kodeks Ukrai'ny pro administratyvni pravoporushennja, vid 7 grudnja 1984, No. 8073-X, red. vid 5 travnja, [Online], available at: http://zakon3.rada.gov.ua/laws/show/80731-10 
2. Verhovna Rada Ukrai'ny (2014), Pro zasady derzhavnoi' antykorupcijnoi' polityky v Ukrai'ni (Antykorupcijna strategija) na 2014-2017 roky, Zakon, No. 1699-VII, vid 14 zhovt., red. vid 8 serp. 2015, [Online], available at: https://zakon.rada.gov.ua/laws/show/1699-18

3. Verhovna Rada Ukrai'ny (2014), Pro zapobigannja korupcii', Zakon, No. 1700VII, vid 14 zhovt., red. vid 16 lypnja 2019, [Online], available at: http://zakon4.rada.gov.ua/laws/show/170018

4. Verhovna Rada Ukrai'ny (2015), Pro Nacional'nu policiju, Zakon, No. 580-VIII, vid 2 lypnja, red. vid 1 sichnja 2019, [Online], available at: https://zakon.rada.gov.ua/laws/show/580-19

5. Verhovna Rada Ukrai'ny (2014), Pro Nacional'ne antykorupcijne bjuro Ukrai'ny, Zakon, No. 1698-VII, vid 14 zhovt., red. vid 5 chervnja 2018, [Online], available at: https://zakon.rada.gov.ua/laws/show/1698-18

6. Verhovna Rada Ukrai'ny (2014), Pro prokuraturu, Zakon, No. 1697-VII vid 14 zhovt. (v redakcii' vid 28.08.2018), [Online], available at: https://zakon.rada.gov.ua/laws/show/1697-18

7. Al'-Atti, I.V. (2018), «Publichne upravlinnja: sutnist' i vyznachennja», Aspekty publichnogo upravlinnja, Vol. 6, No. 8, pp. 35-41.

8. Bytjak, Ju.P., Garashhuk, V.M. and. D'jachenko, O.V. (2007), Administratyvne pravo Ukrai'ny, in Bytjak, Ju.P. (ed.), Jurynkom Inter, Kyi'v, 543 p.

9. Goncharuk, N.T. and Suraj, I.G. (2010), «Vplyv rozvytku gromadjans'kogo suspil'stva na publichne upravlinnja», Derzhavne upravlinnja: istorija, teorija, vprovadzhennja, materialy nauk.-prakt. konf. za mizhnar. uchastju, 28 trav., NADU, Kyi'v, Vol. 1, pp.145-146.

10. Kobzar, O.F. (2017), «Vzajemodija - nevid'jemna skladova upravlinnja v pravoohoronnij dijal'nosti», Naukovi zapysky Central'noukrai'ns'kogo derzhavnogo pedagogichnogo universytetu imeni Volodymyra Vynnychenka, Serija Pravo, Issue 2 (specvyp.), pp. 71-74.

11. Mel'nyk, R.S. (2012), «Kategorija «publichne upravlinnja»u novij interpretacii'», Pravo i susil'pstvo, No. 6, pp. 95-98.

12. Novak-Kaljajeva, L.M. (2015), «Dejaki aspekty formuvannja novitn'oi' paradygmy publichnoi' vlady na zasadah prav ljudyny», Efektyvnist' derzhavnogo upravlinnja, Issue 45, pp. 41-47.

13. Nyzhnyk, N.R., Goncharuk, N.T. and Tolstouhov, A.V. (ed.) (2010), Publichna administracija v Ukrai'ni: stanovlennja ta rozvytok, in Monolit, Dnipropetrovs'k, $400 \mathrm{p}$.

14. Voronkova, V., Banah, V., Sosnin, O.P. and others (2016), Publichne upravlinnja ta administruvannja $v$ umovah informacijnogo suspil'stva: vitchyznjanyj i zarubizhnyj dosvid, in Chernov, S. (ed.), ZDIA, Zaporizhzhja, 606 p.

15. Kujbida, V.S., Bilyns'ka, M.M., Petroje, O.M. and ofhers (uklad.) (2018), Publichne upravlinnja, NADU, Kyi'v, $224 \mathrm{p}$

16. Savenjuk, V.V. (2018), Modernizacija systemy publichnoi' vlady v administratyvnomu rajoni Ukrai'ny, Abstract of the Ph.D. dissertation, spec. 25.00.04 misceve samovrjaduvannja, Nacional'na akademija derzhavnogo upravlinnja pry Prezydentovi Ukrai'ny, Kyi'v, 20 p.

17. Sharov, Ju. and Chykarenko, I., Jevropejs'ki standarty publichnogo upravlinnja: proekcija na municypal'nyj riven', [Online], available at: www.nbuv.gov.ua

Кучменко Віталій Олександрович - кандидат економічних наук, доцент кафедри економічної безпеки, публічного управління та адміністрування Державного університету «Житомирська політехніка».

Наукові інтереси:

- управління транспортною системою міста;

- механізми публічного управління та адміністрування.

Івченко Олександр Михайлович - магістрант факультету публічного управління та права Державного університету «Житомирська політехніка», спеціальність 262 «Правоохоронна діяльність».

Наукові інтереси:

- реформування правоохоронних органів в країні;

- антикорупційна діяльність в органах державної влади.

Герасимчук Олександр Миколайович - магістрант факультету публічного управління та права Державного університету «Житомирська політехніка», спеціальність 281 «Публічне управління та адміністрування».

Наукові інтереси:

- функції правоохоронних органів у сфері забезпечення публічної безпеки;

- механізми подолання корупції в державі. 